\title{
Using salinity to identify common bottlenose dolphin habitat in Barataria Bay, Louisiana, USA
}

\author{
Fawn E. Hornsby ${ }^{1, *}$, Trent L. McDonald ${ }^{1}$, Brian C. Balmer ${ }^{2}$, Todd R. Speakman ${ }^{2}$, \\ Keith D. Mullin ${ }^{3}$, Patricia E. Rosel ${ }^{4}$, Randall S. Wells ${ }^{5}$, Andrew C. Telander ${ }^{1}$, \\ Peter W. Marcy ${ }^{1}$, Kristen C. Klaphake ${ }^{1, * *}$, Lori H. Schwacke ${ }^{2}$ \\ ${ }^{1}$ Western EcoSystems Technology, Inc., Laramie, WY 82072, USA \\ ${ }^{2}$ National Centers for Coastal Ocean Science, National Oceanic and Atmospheric Administration, Hollings Marine Laboratory, \\ Charleston, SC 29412, USA \\ ${ }^{3}$ Southeast Fisheries Science Center, National Marine Fisheries Service, NOAA, Pascagoula, MS 39568, USA \\ ${ }^{4}$ Southeast Fisheries Science Center, National Marine Fisheries Service, NOAA, Lafayette, LA 70506, USA \\ ${ }^{5}$ Sarasota Dolphin Research Program, Chicago Zoological Society, c/o Mote Marine Laboratory, Sarasota, FL 34236, USA
}

\begin{abstract}
Following the Deepwater Horizon (DWH) oil spill, numerous studies were conducted to determine impacts on common bottlenose dolphins Tursiops truncatus. Common bottlenose dolphins are found in estuarine environments of the northern Gulf of Mexico which vary in salinity, depending on location (e.g. distance to freshwater source), season, and ocean tides. Although common bottlenose dolphins can be found in low-salinity waters $(<15 \mathrm{ppt})$, they cannot tolerate very low salinity for long periods of time. We matched dolphin telemetry data in Barataria Bay, Louisiana (USA), with contemporaneous estimates of salinity to establish a salinity threshold and identify preferred dolphin habitat. Dolphins frequently used areas where salinity was higher than $\sim 11 \mathrm{ppt}$, sometimes used areas for short periods of time with predicted salinity of $\sim 8 \mathrm{ppt}$, and avoided waters with salinities below $\sim 5$ ppt. While not a hard boundary, the $\sim 8$ ppt threshold can be used to delineate reasonable polygons of preferred dolphin habitat. We temporally averaged the location of the $\sim 8$ ppt isohaline from 2005 through 2012 to establish areas of preferred dolphin habitat. In Barataria Bay, the polygon of dolphin habitat encompasses $1167 \mathrm{~km}^{2}$, and extends from the bay's barrier islands to approximately half-way through marshes in northern parts of the bay. This polygon of suitable common bottlenose dolphin habitat was then ultimately used to quantify cetacean injury due to DWH oil.
\end{abstract}

KEY WORDS: Tursiops truncatus · Habitat - Deepwater Horizon · Barataria Bay · Telemetry · Salinity $\cdot$ Photo-ID

\section{INTRODUCTION}

Common bottlenose dolphins Tursiops truncatus have been found in many bay, sound, and estuarine (BSE) environments (Waring et al. 2015), which are characterized by shallow, brackish waters with highly variable salinity and include areas such as Barataria Bay, located in the northern Gulf of Mexico (GoM) off the southeastern Louisiana (LA) coast, USA (Mullin et al. 1990, USEPA 1999, Vollmer \& Rosel 2013). After

\footnotetext{
*Corresponding author: fhornsby@west-inc.com
}

${ }^{* *}$ Cartographer the Deepwater Horizon (DWH) oil spill began on 20 April 2010, determining contemporary survival and abundance estimates for common bottlenose dolphins in various BSEs, including Barataria Bay, in the northern GoM impacted by the spill became an important objective to determine injury for the Natural Resources Damage Assessment (NRDA). This motivated the development of a novel capture-recapture model (McDonald et al. 2017, this Theme Section), referred to as a spatial robust-design model, to estimate

(C) The authors and (outside the USA) the US Government 2017. Open Access under Creative Commons by Attribution Licence. Use, distribution and reproduction are unrestricted. Authors and original publication must be credited.

Publisher: Inter-Research · www.int-res.com 
survival, and abundance for Barataria Bay using recent photo-identification (photo-ID) data.

Conventional capture-recapture methods result in an estimate of population size for an ill-defined boundary, or effective trapping area (ETA), surrounding the capture-recapture study area (Borchers \& Efford 2008). If the presumed size of the ETA is smaller than the area where an abundance estimate is desired (as was the case for Barataria Bay; see Figs. 1 \& 2 in McDonald et al. 2017), then an assumption about the size of the ETA must be made in order to compute density, which is then multiplied by the total area of interest to calculate the total population size (Borchers \& Efford 2008). The need for this assumption reduces the reliability of the resulting density and abundance estimates (Borchers \& Efford 2008). In comparison, the spatial robust-design capturerecapture model proposed by McDonald et al. (2017) incorporates a habitat mask to directly estimate density. Using the resulting density estimates, abundance could then be estimated by multiplying those densities by the area of the habitat mask. The required habitat mask should include the entire spatial extent of all dolphins' activity centers with nonnegligible probability of being captured within the photo-ID study area as well as all areas where, on average, the resulting density can be reasonably applied (Borchers \& Efford 2008, McDonald et al. 2017).

In this paper, we developed a methodology to identify and estimate the location of preferred common bottlenose dolphin habitat based on salinity for use as the habitat mask described above. A number of biotic and abiotic factors have been examined to study bottlenose dolphin ( $T$. truncatus and $T$. aduncus) habitat use and include prey and predator abundance and distribution, water temperature, salinity, tides, turbidity, dissolved oxygen, physiography, and water depth (e.g. Barco et al. 1999, Heithaus \& Dill 2002, Wirsing et al. 2008, Miller \& Baltz 2009, Bailey \& Thompson 2010, Fury \& Harrison 2011).

Barataria Bay is an estuarine wetland system located in southeastern Louisiana where water depth is relatively constant throughout at $2 \mathrm{~m}$, with some deeper areas dredged for navigation channels. Water temperatures fluctuate seasonally in Barataria Bay (e.g. Joshi \& D'Sa 2015), but are above the lower critical temperature for common bottlenose dolphins $\left(5.5-10.6^{\circ} \mathrm{C}_{i}\right.$ Yeates \& Houser 2008). The thermoneutral zone (TNZ) is the temperature range in which an animal spends little or no energy to maintain its internal temperature (Schmidt-Nielson 1990), and Barco et al. (1999) suggested that migrations of coastal dolphin stocks along the US east coast may be in response to animals that targeted water temperatures within the TNZ $\left(\geq 16^{\circ} \mathrm{C}\right)$. However, BSE dolphins in the more southern latitudes of the GoM, such as Sarasota Bay, Florida, experience yearly temperature ranges between 10 and $18^{\circ} \mathrm{C}$ and are longterm residents of the estuary (Wells 2014), suggesting that either the TNZ varies by population/region or there are other factors influencing habitat selection for northern GoM BSE stocks. In Sarasota Bay, although prey species diversity changes seasonally (Irvine et al. 1981), prey are available year-round (Berens McCabe et al. 2010), which may suggest that both thermal tolerances, prey availability, and predator abundance influence habitat selection. Tidal flux within Barataria Bay varies diurnally, but is small (Conner \& Day 1987) and primarily affects only the lower portion of the estuary. However, salinity in Barataria Bay can vary significantly both spatially and temporally (see Supplement 1 at www.int-res. com/articles/suppl/n033p181_supp1.pdf). Salinity in the upper portion of the bay is low and driven predominantly by evaporation and freshwater input from precipitation (Orlando et al. 1993). Salinity ranges from near 0 in the upper reaches to $\sim 25 \mathrm{ppt}$ in the southern portions of the bay (Das et al. 2012).

Although common bottlenose dolphins inhabit waters with a wide range of salinities, several studies have documented adverse outcomes following extended exposure to very low salinities: dolphins in Lake Pontchartrain, LA, where average salinity measured 4.8 ppt developed severe skin lesions (Mullin et al. 2015), and dolphins exposed to salinities below about 10 ppt exhibited necrosis and ulceration of the epidermis (Simpson \& Gardner 1972). Mortality was reported for dolphins that remained in waters less than $10 \mathrm{ppt}$ for 6 mo (Colbert et al. 1999). Captive dolphins exposed to freshwater for only $3 \mathrm{~d}$ had permanent impacts to epidermis cells, but the impacted skin cells were subsequently shed when returned to saltwater (Harrison \& Thurley 1974). Although an exposure-response relationship considering salinity level, time, and adverse health consequences has not been defined, these studies demonstrate that common bottlenose dolphins will experience negative health effects, such as severe skin lesions, if they inhabit low-salinity waters $(<10-15 \mathrm{ppt}$, approximately) for extended periods. Furthermore, we deduce that the spatially wide-ranging salinities found in Barataria Bay include salinities low enough to be physiologically limiting, and therefore should limit spatial distribution of dolphins within the estuary.

We therefore focused on estimating a salinity threshold to define preferred dolphin habitat, which 
represents a minimum salinity below which the dolphins would rarely be observed. We defined the salinity threshold by temporally matching salinity values from a spatio-temporal kriging model (Supplement 1) with dolphin satellite-linked telemetry observations to determine a habitat-defining threshold. In other words, the salinity threshold serves as the border between waters with salinities that common bottlenose dolphins routinely inhabit and lowersalinity waters that dolphins inhabit for minimal amounts of time. We chose Barataria Bay, LA, to demonstrate these methods, since both salinity and telemetry data exist throughout the same time period. Furthermore, Barataria Bay offered an ideal study area for our analyses in that it exhibits a spatially broad range of salinities, and due to the narrow range of other influential dolphin habitat factors such as temperature, depth, and tidal flux, salinity gradient is likely to be a primary driver for dolphin distribution.

\section{MATERIALS AND METHODS}

The waters within the Barataria Bay common bottlenose dolphin stock boundary defined by NOAA's National Marine Fisheries Service in their annual Stock Assessment Reports (Fig. 1; Waring et al. 2015) represented the total square kilometers of potential common bottlenose dolphin habitat for this analysis. The stock boundary in Barataria Bay extended into the northern reaches of the bay and then south and east just past a string of barrier islands, including Grand Isle and Isle Grande Terre. Using this boundary as our starting point for habitat determination, we developed methodology to combine salinity surfaces (Supplement 1) with common bottlenose dolphin movement data obtained from satellite-linked tag telemetry data (Wells et al. 2017, this Theme Section) to investigate dolphin movements in relation to changing salinity within the Barataria Bay stock area. We identified a reasonable salinity threshold and adopted it as a habitat boundary. Finally, we averaged the daily location of this boundary over multiple years to establish an area of preferred dolphin habitat.

\section{Salinity data}

We compiled a large database comprised of publicly available salinity data from multiple federal and state agencies, as well as a subset of data collected by the 2010-2013 DWH NRDA Oyster Technical Work- ing Group (TWG) (see Supplement 1 \& Supplement 2 at www.int-res.com/articles/suppl/n033p181_supp2. pdf) to estimate a spatio-temporal kriging model (Szpiro et al. 2009, Sampson et al. 2011, Lindström et al. 2014) in Barataria Bay and other BSEs of the northern GoM (Supplement 1). This model predicted daily salinity (in ppt) at points in a $200 \times 200 \mathrm{~m}$ grid overlaying Barataria Bay. The kriging model developed in Supplement 1 estimated a smooth salinity surface for the entire Barataria Bay stock area for every day of the study period (2005-2012). Model validation against an independent dataset collected in 2011 by the DWH NRDA Fish TWG (NOAA 2011a,b) showed a high correlation between predicted and measured salinity $(\rho=0.93$; Supplement 1$)$. Discrepancies between predicted and measured salinity primarily occurred in areas with measured salinity below 15 ppt (Supplement 1). In those areas where salinities fell below $15 \mathrm{ppt}$, the model, on average, under-predicted salinity by 1.86 , or approximately 2 ppt (Supplement 1).

\section{Dolphin movement data}

In Barataria Bay, the most recent source of information about dolphin movements comes from a NRDA telemetry study conducted by Wells et al. (2017), who placed satellite-linked SPOT-100 transmitters (Wildlife Computers) on 25 common bottlenose dolphins in Barataria Bay during capture-release health assessments beginning in August 2011. The majority of tags transmitted 1 or 2 high-quality locations per day for each individual and lasted 2 to 3 mo (see Wells et al. 2017 for details on tag transmission rates). Satellitelinked locations were received and processed by the Argos Data Collection and Location System. During analysis, locations with low plausibility were deleted and only locations with estimated Argos error $<500 \mathrm{~m}$ were used. With these criteria, Wells et al. (2017) collected 3765 usable telemetry locations between $3 \mathrm{Au}$ gust 2011 and 10 April 2012 (Fig. 2) for the 25 tagged dolphins. Finally, the summation of each dolphin's total number of days with a successfully transmitted location was equal to 2009 dolphin-days.

\section{Identifying a salinity threshold}

Using the salinity products and telemetry data, we linked estimated salinity levels with dolphin locations in 3 steps. First, we paired dolphin telemetry locations with the closest available salinity grid cell 


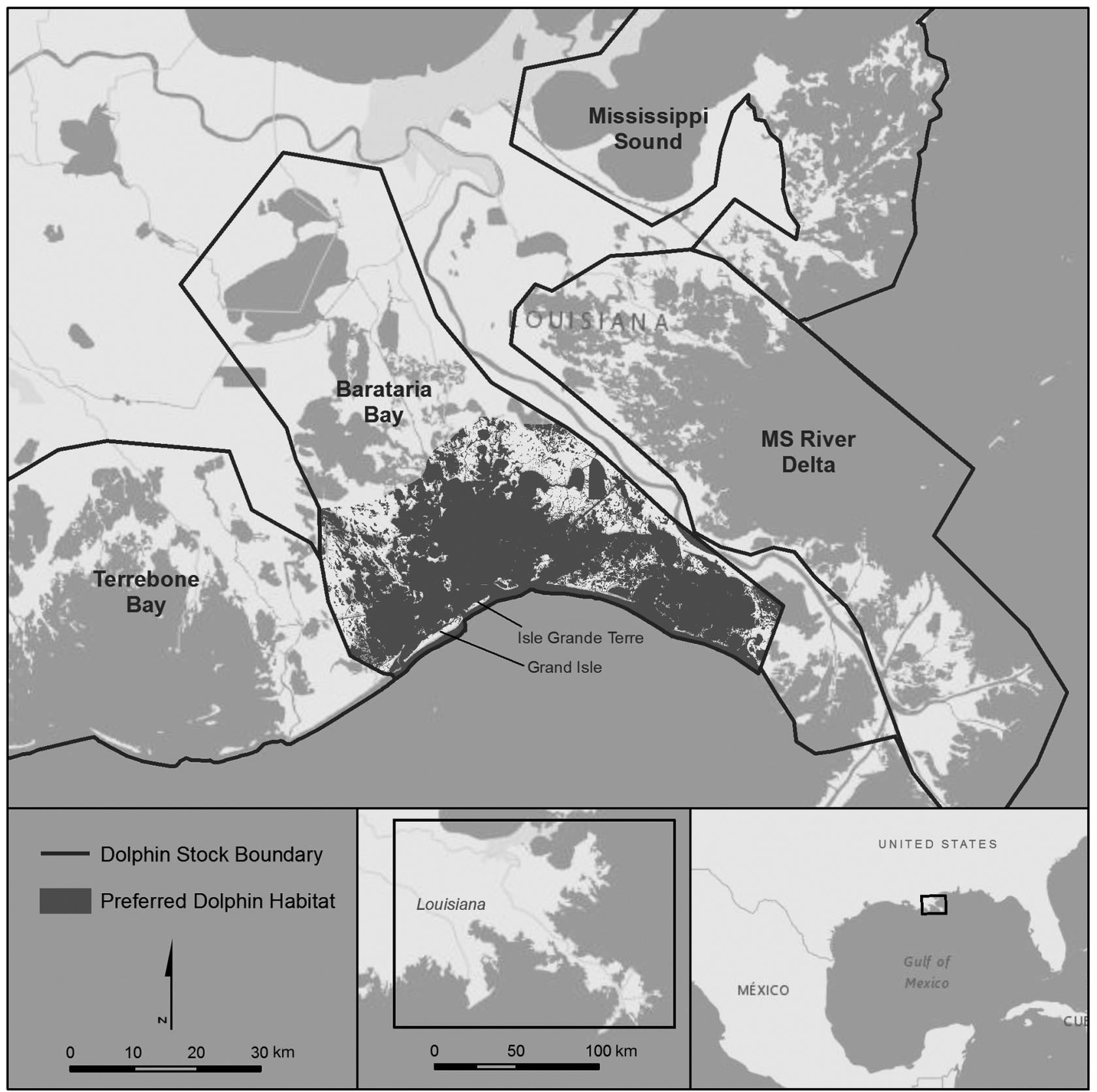

Fig. 1. Preferred common bottlenose dolphin Tursiops truncatus habitat for the Barataria Bay (Louisiana, USA) stock based on the identified salinity threshold of $\sim 8$ ppt (dark shaded areas). NMFS stock boundaries for the Barataria Bay stock and adjacent estuarine stocks to the west and east are also shown. The estimated amount of preferred dolphin habitat within Barataria Bay averages $1167 \mathrm{~km}^{2}$

center point (Fig. 3). Second, we queried salinity values for that cell and the 8 surrounding cells on the same day that the telemetry location occurred. In total, we queried an area approximately $\pm 300 \mathrm{~m}$ in cardinal directions $( \pm 425 \mathrm{~m}$ diagonally) because errors in telemetry locations were less than $\pm 500 \mathrm{~m}$. For the third and final step, we averaged the 9 queried salinity estimates to produce an average value, which approximated the salinity level that the dolphin experienced on the day of the observed telemetry location. We excluded telemetry locations greater than $200 \mathrm{~m}$ outside of the stock boundary. Near the edges of the stock boundary, 9 grid cells were not always available. In these cases, we queried salinity values from the closest grid cell and whichever of the remaining 8 surrounding grid cells existed. 


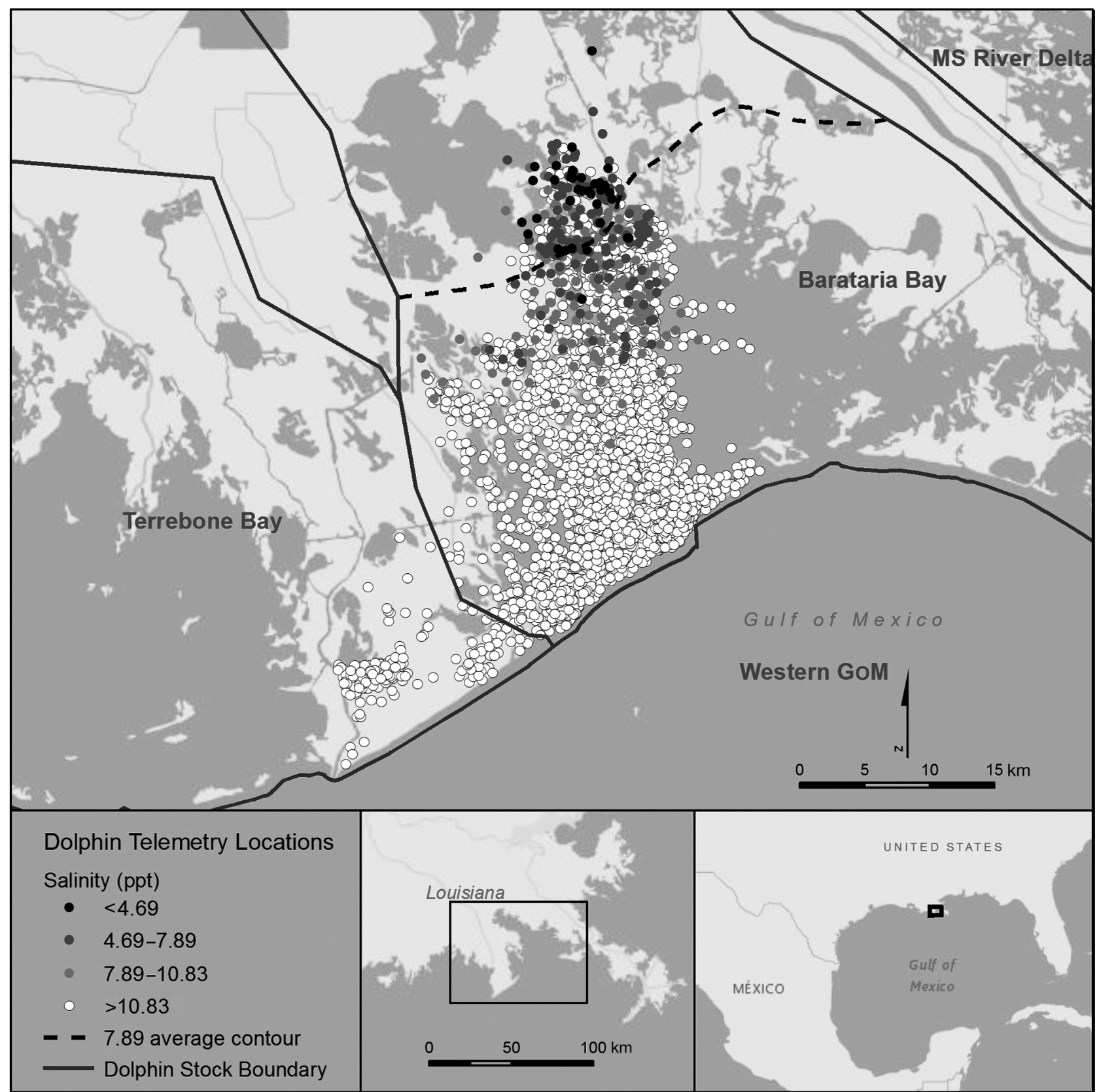

Fig. 2. Satellite-linked telemetry locations for 25 common bottlenose dolphins Tursiops truncatus and estimated salinity for each location in Barataria Bay, LA. The 7.89 , or $\sim 8$, ppt average salinity contour (dashed line) was identified using salinity data from 2005 to 2012

From this pairing exercise, we generated a locationassociated distribution of salinity values (Fig. 4).

We selected the 1st, 5th, 10th, 15th, 20th, and 25th percentiles in the lower tail of the location-associated salinity distribution (Fig. 4) as candidate values for the salinity threshold. We then based the choice of salinity threshold on visual inspection of the relationship between dolphin movement and salinity as well as various summaries of the resulting salinity distri- bution. To carry out our visual inspection, we plotted each individual's telemetry location(s) on the corresponding day's predicted salinity surface. For example, Fig. 5 shows 1 such plot containing the locations of dolphin Y14 on 21 and 22 August 2011 with the estimated salinity surface on 22 August 2011. Fig. 5 also shows the contour lines associated with the 1 st, 5 th, and 10th percentiles from the salinity distribution. We viewed these plots for each individual sequentially (in 


\begin{tabular}{|c|c|c|c|c|c|c|c|c|c|}
\hline$\times$ & $x$ & $x$ & $x$ & $\times$ & $x$ & $x$ & $x$ & $x$ & $x$ \\
\hline$x$ & $x$ & $x$ & $x$ & $\times$ & $x$ & $x$ & $x$ & $x$ & $x$ \\
\hline$x$ & $x$ & $x$ & $x$ & $x$ & $x$ & $x$ & $x$ & $x$ & $x$ \\
\hline$\times$ & $x$ & $x$ & $x$ & $\times$ & $\times$ & $\times$ & $x$ & $x$ & $\mathrm{x}$ \\
\hline$\times$ & $x$ & $x$ & $x$ & $x^{0}$ & $\times$ & $\times$ & $x$ & $x$ & $x$ \\
\hline$\times$ & $x$ & $x$ & $x$ & $\times$ & $x$ & $\times$ & $x$ & $x$ & $x$ \\
\hline$x$ & $x$ & $x$ & $x$ & $\times$ & $x$ & $x$ & $x$ & $x$ & $x$ \\
\hline$\times$ & $x$ & $x$ & \multirow{3}{*}{$\begin{array}{l}\square \\
\times \\
\square \\
0\end{array}$} & \multirow{3}{*}{\multicolumn{5}{|c|}{$\begin{array}{l}200 \times 200 \text { m salinity grid cell } \\
\text { Salinity grid cell centerpoint } \\
\text { Matched salinity grid cell } \\
\text { Telemetry location }\end{array}$}} & \\
\hline$\times$ & $\times$ & $x$ & & & & & & & \\
\hline$x$ & $x$ & $x$ & & & & & & & \\
\hline
\end{tabular}

Fig. 3. Process used to match telemetry locations of common bottlenose dolphins Tursiops truncatus with a salinity value. First, each telemetry location was matched to the closest grid cell. Next, the salinities from that cell and the surrounding 8 grid cells (shown in gray) were queried. Finally, these 9 salinities were averaged, thereby linking a single salinity value to each telemetry location

an animation) and inspected the individual's movements in relation to salinity.

We calculated the number of consecutive days on which each individual dolphin's transmitted location occurred at or below each salinity percentile of interest. We then summarized the resulting dataset for each salinity percentile in a variety of ways. First, we determined the number of dolphins that were recorded in waters at or below each salinity percentile. Then, we summarized the number of consecutive days each dolphin spent in waters at or below each salinity percentile. Further, we counted the number of times that a dolphin was detected in waters with salinity below a given percentile. Lastly, to get an approximate idea of how many days the dolphins 'stayed' at or below each salinity percentile, we summed the number of dolphin-days that dolphins were found at or below each salinity percentile. Although dolphins may not have strictly remained in waters at or below any given percentile, this final summary provided another glimpse into dolphin behavior at certain salinities.

Based on plots similar to Fig. 5, we chose the salinity threshold as the contour (and associated salinity) from our candidate percentiles with the highest number of day-to-day crossings. We reasoned that if dolphins tolerated a certain level of salinity, we could expect random movements rela-
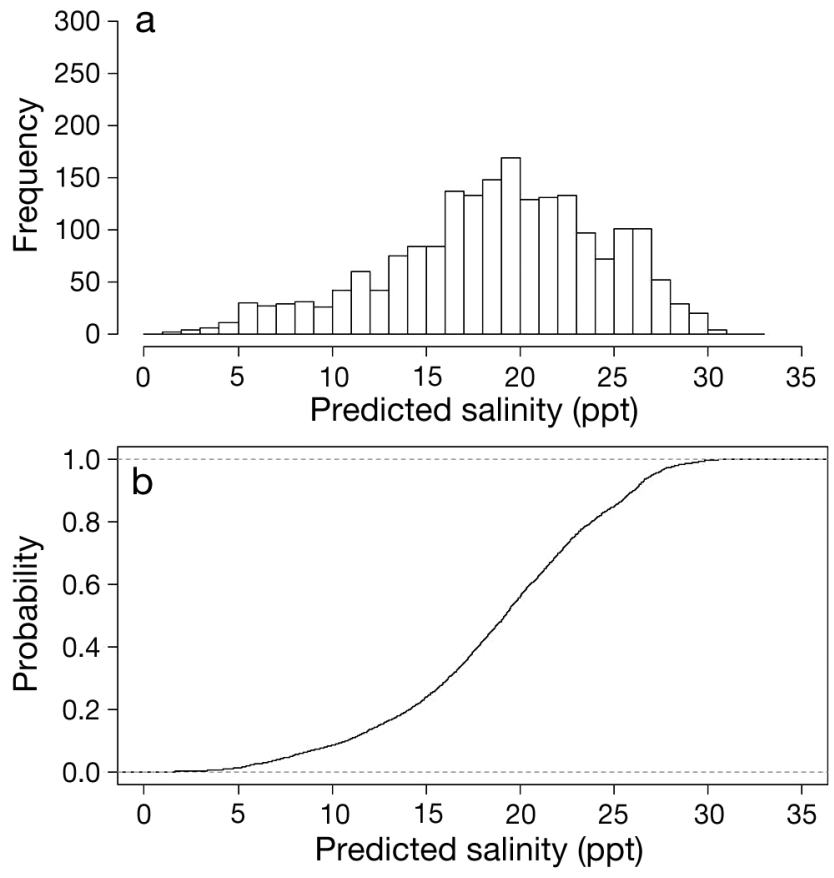

Fig. 4. (a) Location-associated distribution of salinity values for satellite-tagged common bottlenose dolphins Tursiops truncatus in Barataria Bay, LA. Salinity values were matched temporally and spatially to dolphin locations by averaging over the $200 \times 200 \mathrm{~m}$ grid cells $(\mathrm{n}=9)$ surrounding the location. (b) Cumulative distribution of the location-associated distribution of salinity values. The probabilities on the $y$-axis correspond to our candidate percentiles (i.e. 1, 5, 10, 15, 20, and $25 \%$ ). The 1 st percentile corresponds to $4.69 \mathrm{ppt}$, the 5th percentile corresponds to $7.89 \mathrm{ppt}$, the 10 th percentile corresponds to $10.83 \mathrm{ppt}$, the 15 th percentile corresponds to $12.58 \mathrm{ppt}$, the 20th percentile corresponds to $14.19 \mathrm{ppt}$, and the 25 th percentile corresponds to $15.26 \mathrm{ppt}$

tive to a contour of this level. Random movements imply a relatively low number of contour crossings. For example, if dolphins tolerate 15 ppt salinity for extended periods, we expect only random crossings day-to-day with extended periods in waters with salinity both below and above $15 \mathrm{ppt}$. If dolphins only marginally tolerate a certain level of salinity, we expected a relatively large number of movements from salinities below that level to salinities above that level. That is, we expected dolphins below a marginally tolerated threshold to cross over the threshold many times day-to-day relative to other contours. For example, if dolphins do not tolerate salinities below $8 \mathrm{ppt}$ for long periods, we expected to see dolphins move to a position in salinities above 8 ppt soon after (e.g. 1 to 2 d) being located in a position below 8 ppt, and we did not expect to see many consecutive days (fewer than 1 or $2 \mathrm{~d}$ ) in waters with salinity below $8 \mathrm{ppt}$. 


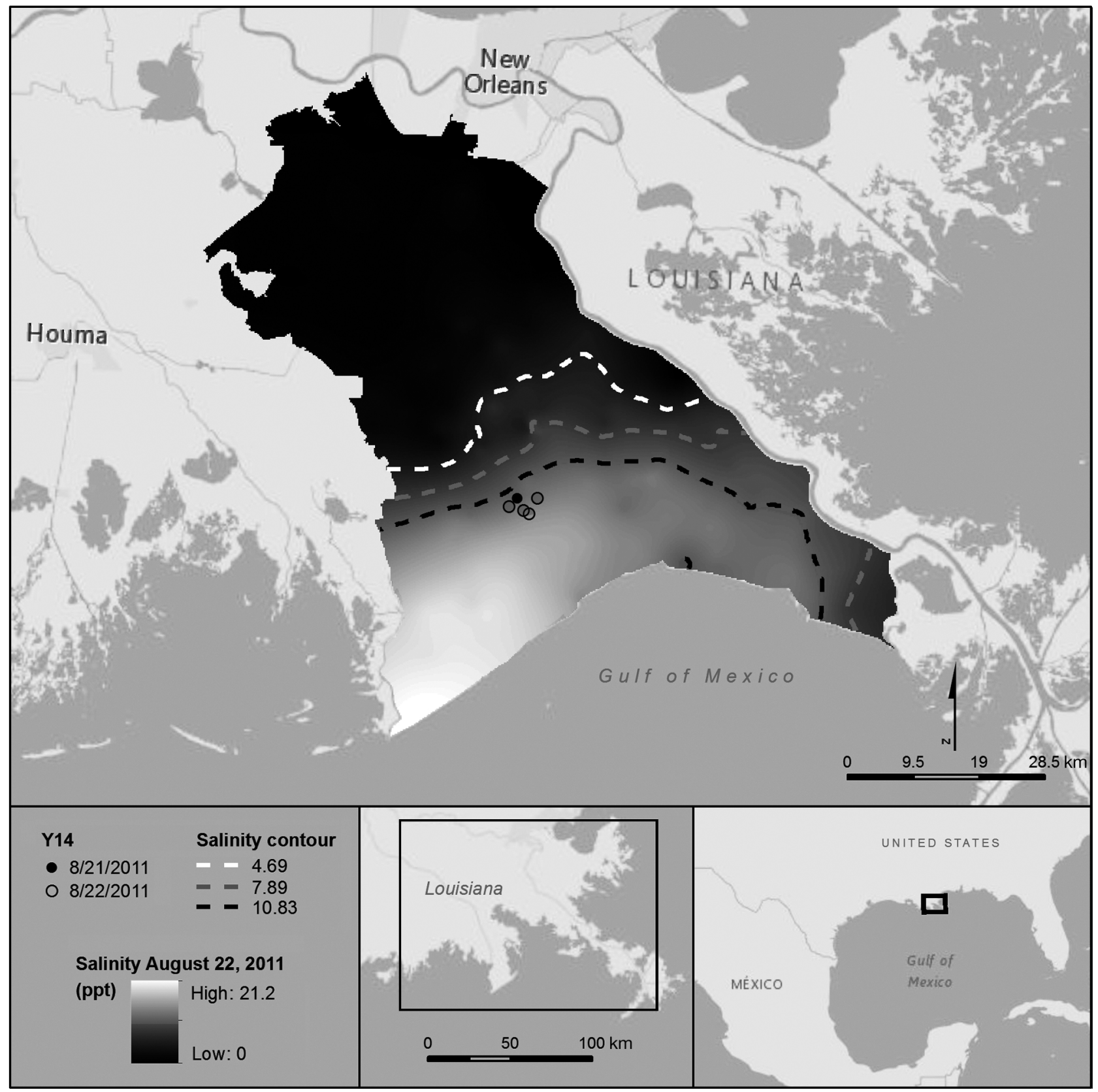

Fig. 5. Telemetry location (filled circle) for common bottlenose dolphin Tursiops truncatus Y14 on 22 August 2011 plotted on the salinity surface from the spatio-temporal kriging model. This figure also shows Y14's telemetry locations (open circles) from the previous day. The salinity contour lines (white, light gray, and dark gray dashed lines; measured in ppt) shown correspond to the 1st, 5th, and 10th percentiles of the salinity distribution for the salinity surface on 22 August 2011

\section{Characterizing preferred dolphin habitat}

Once the salinity threshold was established, we sought to characterize its average location in Barataria Bay over time. We determined average geographic placement of the salinity threshold in 3 steps. First, we estimated a single long-term average salinity surface by calculating a temporal average in each
$200 \times 200 \mathrm{~m}$ grid cell over all days between 1 January 2005 and 31 December 2012 ( $\mathrm{n}=2922$ d). Second, we plotted the chosen salinity threshold contour on the long-term average salinity surface. This contour, on the long-term average salinity surface, served as our border distinguishing preferred habitat in the southern part of the bay from non-preferred habitat in the northern part of the bay. 
The third and final step to determine preferred dolphin habitat involved excluding land. Using ArcGIS v10.3, we clipped areas with average salinity greater than the threshold to a recent land-water shapefile (ERMA 2015; updated 19 January 2012). This shapefile layer, titled '2008 Land/water Interface as of 9/14/2012 (USGS) (NOAA)(PDARP)' and located in the parent folder: Bathymetry \& Hydrology $>$ Shoreline, consisted of polygons designating all areas of Barataria Bay as either land or water. Once land was removed from the delineated habitat, the remaining area characterized preferred dolphin habitat.

\section{RESULTS}

A total of 3581 dolphin satellite tag-telemetry points fell inside the $200 \times 200$ m salinity grid overlaying the Barataria Bay stock area and were therefore matched with average salinity calculated from the surrounding 9 cells. Telemetry points occurred in waters with salinity between 1.61 and 32.08 ppt. The 1st, 5th, 10th, 15th, 20th, and 25th candidate percentiles of the location-associated salinity distribution corresponded to predicted salinity values of $4.69,7.89,10.83,12.58$, 14.19, 15.26 ppt, respectively (Fig. 4).

The potential habitat area (i.e. water-only areas within the Barataria Bay stock boundary) consisted of a total of $1791 \mathrm{~km}^{2}$. However, Fig. 2 shows that the satellite-tagged dolphins did not venture into the northernmost reaches of the bay, where 29.588 was the highest recorded latitude and predicted salinity was 4.63 ppt. From visual inspection of figures similar to Fig. 5, dolphins predominantly remained in waters with salinity $<8$ ppt for less than $24 \mathrm{~h}$. Additionally, dolphins recorded in lower salinity waters tended to remain in the vicinity of the $8 \mathrm{ppt}$ isohaline and did not often venture into waters much below 8 ppt salinity. We did not observe these associations around other salinity contours. Eight ppt was close to the 5 th percentile of salinity estimated at the time and place of dolphin locations (7.89 ppt, Fig. 4). We therefore focused additional effort on choosing between the 5th and its surrounding candidate percentiles of 1 and 10 .

The total habitat area with land removed and average salinities higher than the $1 \mathrm{st}, 5$ th, and 10th percentiles totaled 1329, 1167, and $1048 \mathrm{~km}^{2}$, respectively. Thus, the 1st, 5th, and 10th percentiles represented $74 \%(=1329 / 1791), 65 \%(=1167 / 1791)$, and $58 \%$ $(=1048 / 1791)$ of the total potential habitat area, respectively. Upon further inspection of dolphin movements in relation to the 5 th percentile, the data showed that only 5 out of the 25 tagged dolphins (=20\%) entered waters with salinity less than approximately 8 ppt for a total of 48 times and 'stayed' (as defined in the 'Materials and methods' section) there for 99 out of 2009 dolphin-days (Fig. 6b). Furthermore, during 30 of those occasions $(30 / 48=62.5 \%)$, the dolphins returned to higher salinity waters within $24 \mathrm{~h}$. In other words, when a dolphin ventured into waters less than approximately $8 \mathrm{ppt}, 62.5 \%$ of the time they left for higher salinity within $24 \mathrm{~h}$. Comparatively, over one-third $(9 / 25=36 \%)$ of satellitetagged dolphins entered waters with predicted salinities less than 10.83 ppt a total of 77 times and 'stayed' there for 195 dolphin-days (Fig. 6c). These results indicated that dolphins had increased toler-

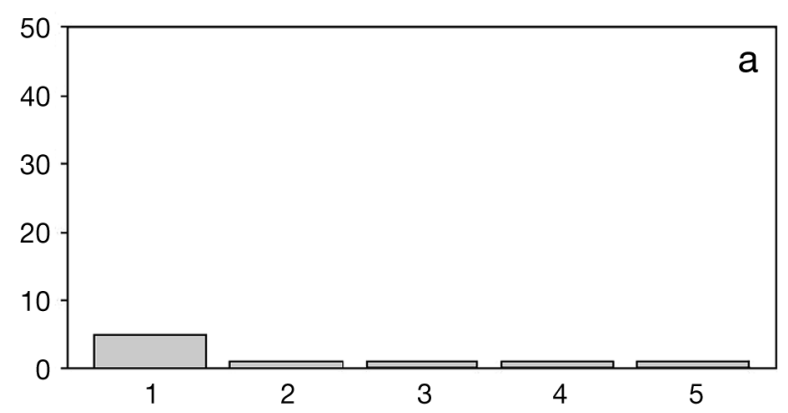

No. of consecutive days in salinity $<4.69$ ppt
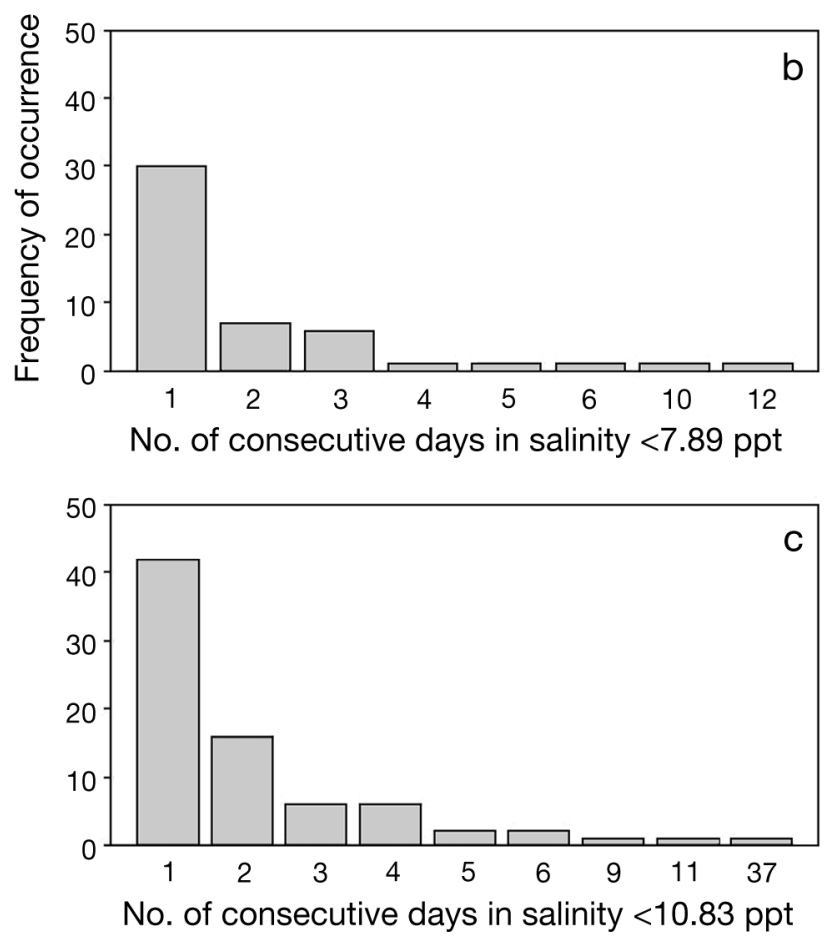

Fig. 6. Number of consecutive days that common bottlenose dolphins Tursiops truncatus spent in salinity less than (a) 4.69, (b) 7.89, and (c) 10.83 ppt in Barataria Bay, LA 
ance for salinities around $10.83 \mathrm{ppt}$. As another comparison to the 5th percentile, only 4 dolphins entered waters with salinity $<4.69 \mathrm{ppt}$ a total of 9 times and 'stayed' there for 19 dolphin-days (Fig. 6a). Given how seldom dolphins entered waters with salinities $<4.69 \mathrm{ppt}$, this salinity percentile most likely represents habitat that dolphins rarely utilize.

Consequently, the 5th percentile, or $\sim 8 \mathrm{ppt}$, was chosen as the salinity threshold since it seemed to be a good compromise between rarely used habitat that dolphins tolerate for only short periods of time, and well-tolerated 10th salinity percentile habitat. Next, we identified waters with average salinity higher than $\sim 8$ ppt as preferred habitat, and the location of the $\sim 8$ ppt contour on the average salinity map appears in Fig. 2. After subtracting land polygons, the area of preferred dolphin habitat in Barataria Bay averaged across years totaled $1167 \mathrm{~km}^{2}$ (Fig. 1).

\section{DISCUSSION}

By combining salinity data with dolphin movement data, we were able to infer a salinity threshold of $\sim 8$ ppt. Dolphins frequently used waters with higher salinities, were present for short periods of time in waters around 8 ppt salinity, and were very rarely found in waters with salinities below $\sim 8$ ppt. The selection of this value allowed for the explicit classification of the extent of preferred dolphin habitat within Barataria Bay's waters. To our knowledge, the explicit identification of preferred dolphin habitat in Barataria Bay has not been previously published and serves to broaden knowledge about dolphin salinity and habitat preferences.

The value of $\sim 8 \mathrm{ppt}$ provides a reasonable salinity threshold value which we can use to explicitly identify an approximate area of preferred dolphin habitat. This represents a threshold below which dolphins were rarely observed. However, it should be noted that even though dolphins were documented in waters around $8 \mathrm{ppt}$, this does not represent a salinity at which the dolphins were necessarily likely to remain for long periods of time. Conversely, it should be noted that dolphins can inhabit waters with salinity below this threshold for short periods of time without ill health effects, but that exposure to salinities near this threshold for an extended period of time is likely to have negative health effects. Some unquantifiable error associated with the choice of a single salinity threshold value exists since it is not a hard boundary. While a range could have been chosen to serve as the salinity threshold instead of a sin- gle value, a single value allows for an explicit delineation of habitat and an estimate of total area. These 2 products were necessary to produce an accurate estimate of abundance using the spatial robustdesign model from McDonald et al. (2017).

Common bottlenose dolphin telemetry locations were used to derive a salinity distribution to represent dolphins' salinity preferences. To help us choose a single value as the salinity threshold, we selected a few percentiles from the location-associated salinity distribution to narrow down the choice of possible candidates. The 1st, 5th, 10th, 15th, 20th, and 25th candidate percentiles were chosen because we believed that these percentiles provided reasonable coverage of the lower tail of the derived salinity distribution (Fig. 4). Error associated with the telemetry locations and error associated with the estimated salinity surface may introduce some uncertainty to the model. The error associated with the dolphin telemetry locations was small $(<500 \mathrm{~m})$ relative to the area of the 9 associated salinity grid cells. Even though Supplement 1 showed that the spatio-temporal model underestimated salinities by about $2 \mathrm{ppt}$ when salinities fell below approximately $15 \mathrm{ppt}$, we consider this bias inconsequential to our analysis since the derived distribution of salinities and the final habitat extent were both created using output from the same model. That is, if salinity estimates are approximately 2 ppt lower than actual values, the contour associated with our salinity threshold would nonetheless be in approximately the same location because the contour was derived from a percentile of the salinity distribution, which in turn was derived from the slightly low salinity surfaces.

Our results suggest that, behaviorally, common bottlenose dolphins appeared to favor waters with salinity $>8$ ppt in Barataria Bay. Although some tagged common bottlenose dolphins did occasionally venture into waters with salinity below $8 \mathrm{ppt}$, they moved out of those waters into higher salinity waters within $24 \mathrm{~h}$. Whether common bottlenose dolphins can sense salinity concentrations is not known, but analyses of taste receptor genes suggests that cetaceans retain only the taste modality for salt (Feng et al. 2014, Zhu et al. 2014). Common bottlenose dolphins could also use environmental cues as proxies for salinity, such as presence of certain fish species, buoyancy, or water turbidity. In many cases, these factors most likely correlate with salinity found within the estuarine environments of the GoM (e.g. Peterson \& Ross 1991, Geiger et al. 2011).

Although our results suggest that salinity is an indicator for identifying BSE dolphin habitat, additional 
variables, such as prey selection and predator avoidance, likely also influence habitat selection. As previously discussed, the movements of dolphins in Barataria Bay in relation to changing salinity could actually be cued by the movements of prey in response to the changing salinity. If so, then other seasonal drivers of prey distribution may also influence dolphin movements. In Shark Bay, Australia, Heithaus \& Dill (2002) determined that prey selection and predator avoidance both play a role in dolphin habitat use. During seasons in which tiger sharks Galeocerdo cuvier were present, dolphins avoided habitat with abundant prey but also higher risk of shark predation. During seasons in which tiger sharks were absent, dolphin distribution shifted back to habitat in which prey was abundant. However, the relevance of these observations in Indo-Pacific bottlenose dolphins from a relatively open bay habitat to dolphins living in the shallow estuarine habitat of Barataria Bay is unclear. Future research investigating dolphin prey abundance and distribution, and determining the density and habitat use of dolphin predators in Barataria Bay will further our understanding of other factors that may be influencing dolphin habitat selection in this region.

In general, the responses of cetaceans to variations in the salinity of the water they inhabit are not well understood and are probably complex. The salinity exposure-response relationship and the period of exposure for common bottlenose dolphins to maintain optimal health in the wild is not well defined and would be influenced by a number of factors including age, general health, water temperature, and the quality and type of prey. However, it is clear that exposure to low-salinity waters for extended periods of time results in negative impacts on dolphin health (e.g. Simpson \& Gardner 1972, Colbert et al. 1999, Mullin et al. 2015). External skin lesions resulting from low salinities are the impacts most readily observed on individual dolphins; however, other internal physiological health issues are possible (Wilson et al. 1999) since mammals must maintain the electrolyte concentration and the volume of internal fluids within very narrow ranges to survive (Costa 2009). Wilson et al. (1999) found skin lesions on common bottlenose dolphins in 10 different geographic areas and suggested that potential biological mechanisms common to those differing areas included chronic physiological stress from exposure to the low salinities or damage to epidermal cells, resulting in electrolyte imbalance, damage to the skin, and increased susceptibility to pathogens in the water.
In low-salinity waters, the osmoregulatory systems of common bottlenose dolphins have demonstrated the ability to compensate for at least some period of time for metabolic derangements even if the skin has lesions associated with fresh water. For example, in Lake Pontchartrain, LA, a large number of common bottlenose dolphins (>20 individuals) survived and, in some cases, reproduced, for over $2.5 \mathrm{yr}$ in waters where the average measured salinity was $4.8 \mathrm{ppt}$ ( $\mathrm{SD}=2.69$, range 1.4-9.2; Mullin et al. 2015). However, nearly all of these dolphins developed skin lesions, many severe, and eventually most likely died as a result of the impaired state caused by either low salinity (and other associated effects such as susceptibility to disease), or in combination with a cold water event (Mullin et al. 2015). Given the length of time the Lake Pontchartrain dolphins survived with compromised health, as indicated by skin condition at lower salinities, our $\sim 8 \mathrm{ppt}$ isohaline preferred habitat boundary does not seem unreasonable. Barataria Bay dolphins have higher salinity waters available to them and are more likely to tolerate brief drops in salinity and were not noted to have even moderate skin lesions.

Since predicted salinites were developed for 4 additional areas in the northern GoM (Morganza/ Vermilion, Caernarvon, Bonnet Carre, and Mobile Bay; see Supplement 1), preferred common bottlenose habitat could be easily identified in these areas by following the methods outlined in this paper. If telemetry data are available, then they can be matched temporally to predicted salinity, and an updated salinity threshold can be derived specific to the northern GOM BSE of interest. Additionally, survival and abundance estimates can be obtained using the resulting polygon of preferred dolphin habitat area as a habitat mask in the spatial robust-design capturerecapture model proposed by McDonald et al. (2017). Based on the validation analysis in Supplement 1, we estimate that the salinity threshold resulting from other predictive salinity models may be approximately 2 ppt higher, or approximately 10 ppt. For management purposes, we expect that managers may want to choose a more conservative estimate of total habitat area, such as the 15th percentile, since literature suggests that salinity measuring less than about 10-15 ppt would be harmful to dolphins over the long term. Outside of estuarine environments, other factors, such as predator and prey distributions and water depth, would most likely influence dolphin habitat preference more than salinity.

In summary, by integrating dolphin location information with a well-characterized salinity surface in 
Barataria Bay, LA, we were able to identify a salinity threshold value of $~ 8 \mathrm{ppt}_{\text {; }}$ most common bottlenose dolphins in Barataria Bay seemed to avoid salinity conditions below this threshold. Using $\sim 8 \mathrm{ppt}$, we then approximated preferred dolphin habitat area within Barataria Bay's waters and used this area, coupled with dolphin density estimates, to obtain abundance and survival estimates for the Barataria Bay Stock of common bottlenose dolphins as described by McDonald et al. (2017). Finally, the resulting predictions of McDonald et al.'s (2017) analysis were used as inputs for a population model developed by Schwacke et al. (2017, this Theme Section) to quantify injury due to DWH oil in terms of lost cetacean years and time to recovery. This injury quantification as part of the NRDA is the first step to restoration planning, which will attempt to mitigate damage caused by the DWH oil spill.

Acknowledgements. This work was part of the DWH NRDA being conducted cooperatively among NOAA, other federal and state Trustees, and BP PLC. The findings and conclusions in this paper are those of the authors and do not necessarily represent the view of NOAA or of any other natural resource Trustee for the BP/DWH NRDA. Research was conducted under National Marine Fisheries Service Scientific Research Permit Nos. 932-1905/MA-009526 and 779-1633, and research protocols were reviewed and approved by the NOAA Institutional Animal Care and Use Committee.

\section{LITERATURE CITED}

Bailey H, Thompson P (2010) Effect of oceanographic features on fine-scale foraging movements of bottlenose dolphins. Mar Ecol Prog Ser 418:223-233

Barco SG, Swingle WM, McLellan WA, Harris RN, Pabst DA (1999) Local abundance and distribution of bottlenose dolphins (Tursiops truncatus) in the nearshore waters of Virginia Beach, Virginia. Mar Mamm Sci 15:394-408

Berens McCabe EJ, Gannon DP, Barros NB, Wells RS (2010) Prey selection by resident common bottlenose dolphins (Tursiops truncatus) in Sarasota Bay, Florida. Mar Biol 157:931-942

Borchers DL, Efford MG (2008) Spatially explicit maximum likelihood methods for capture-recapture studies. Biometrics 64:377-385

Colbert AA, Scott GI, Fulton MH, Wirth EF and others (1999) Investigation of unusual mortalities of bottlenose dolphins along the mid-Texas coastal bay ecosystem during 1992. NOAA Tech Rep NMFS 147

Conner WH, Day JW Jr (1987) The ecology of Barataria Basin, Louisiana: an estuarine profile. US Fish and Wildlife Service Biol Rep 85(7.13). USFWS, Washington, DC

Costa DP (2009) Osmoregulation. In: Perrin WF, Würsig B, Thewissen JGM (eds) The encyclopedia of marine mammals. Academic Press, San Diego, CA, p 801-806

*Das A, Justic D, Inoue M, Hoda A, Huang H, Park D (2012) Impacts of Mississippi River diversions on salinity gradients in a deltaic Louisiana estuary: ecological and management implications. Estuar Coast Shelf Sci 111:17-26

ERMA (Environmental Response Management Application) (2015) Deepwater Gulf Response Environmental Response Management. Application, National Oceanic and Atmospheric Administration. http://gomex.erma.noaa.gov/ (accessed 1 February 2016)

Feng P, Zheng J, Rossiter SJ, Wang D, Zhao H (2014) Massive losses of taste receptor genes in toothed and baleen whales. Genome Biol Evol 6:1254-1265

Fury CA, Harrison PL (2011) Seasonal variation and tidal influences on estuarine use by bottlenose dolphins (Tursiops aduncus). Estuar Coast Shelf Sci 93:389-395

Geiger EF, Grossi MD, Trembanis AC, Kohut JT, Oliver MJ (2011) Satellite-derived coastal ocean and estuarine salinity in the Mid-Atlantic. Cont Shelf Res 63(Suppl): S235-S242

Harrison RJ, Thurley KW (1974) Structure of the epidermis in Tursiops, Delphinus and Phocoena. In: Harrison RJ (ed) Functional anatomy of marine mammals. Academic Press, London, p 45-71

* Heithaus MR, Dill LM (2002) Food availability and tiger shark predation risk influence bottlenose dolphin habitat use. Ecology 83:480-491

Irvine AB, Scott MD, Wells RS, Kaufman JK (1981) Movements and activities of the Atlantic bottlenose dolphin, Tursiops truncatus, near Sarasota, FL. Fish Bull 79: 671-688

Joshi I, D'Sa EJ (2015) Seasonal variation of colored dissolved organic matter in Barataria Bay, Louisiana, using combined Landsat and field data. Remote Sens 7: 12478-12502

ㄴindström J, Szpiro A, Sampson PD, Oron AP, Richards M, Larson TV, Sheppard L (2014) A flexible spatio-temporal model for air pollution with spatial and spatio-temporal covariates. Environ Ecol Stat 21:411-433

*McDonald TL, Hornsby FE, Speakman TR, Zolman ES and others (2017) Survival, density, and abundance of common bottlenose dolphins in Barataria Bay (USA) following the Deepwater Horizon oil spill. Endang Species Res 33:193-209

Miller CE, Baltz DM (2009) Environmental characterization of seasonal trends and foraging habitat of bottlenose dolphins (Tursiops truncatus) in northern Gulf of Mexico bays. Fish Bull 108:79-86

Mullin KD, Lohoefener RR, Hoggrd W, Roden CL, Rogers CM (1990) Abundance of bottlenose dolphins, Tursiops truncatus, in the coastal Gulf of Mexico. Northeast Gulf Sci 11:113-122

Mullin K, Barry K, Sinclair C, Litz J and others (2015) Common bottlenose dolphins (Tursiops truncatus) in Lake Pontchartrain, Louisiana: 2007 to mid-2014. NOAA Tech Memo NMFS-SEFSC-673. Pascagoula, MS

NOAA (National Oceanic and Atmospheric Administration) (2011a) Submerged oil characterization across multiple habitats for assessment of persistent exposures in nearshore sediments Deepwater Horizon oil spill (DWHOS). www.gulfspillrestoration.noaa.gov/wp-content/uploads/ 2012/05/2011_07_06_NEARSHORE_Submerged-OilNOAA-BP_LA-Signature.redacted2.pdf

NOAA (National Oceanic and Atmospheric Administration) (2011b) Assessment plan for marsh edges and sandy shorelines, Version 5. www.gulfspillrestoration.noaa.gov/wpcontent/uploads/MarshedgeSandyShoreline_AllSigned. Redacted.pdf 
Orlando SP Jr, Rozas LP, Ward GH, Klein CJ (1993) Salinity characteristics of Gulf of Mexico estuaries. NOAA Office of Ocean Resources Conservation and Assessment. Silver Spring, MD

Peterson MS, Ross ST (1991) Dynamics of littoral fishes and decapods along a coastal river-estuarine gradient. Estuar Coast Shelf Sci 33:467-483

Sampson PD, Szpiro AA, Sheppard L, Lindström J, Kaufman JD (2011) Pragmatic estimation of a spatio-temporal air quality model with irregular monitoring data. Atmos Environ 45:6593-6606

Schmidt-Nielson K (1990) Animal physiology: adaptation and environment, 4th edn. Cambridge University Press, New York, NY

Schwacke LH, Thomas L, Wells RS, McFee WE and others (2017) Quantifying injury to common bottlenose dolphins from the Deepwater Horizon oil spill using an age-, sex-, and class-structured population model. Endang Species Res 33:265-279

Simpson JG, Gardner MB (1972) Comparative microscopic anatomy of selected marine mammals. In: Ridgeway SH (ed) Mammals of the sea: biology and medicine. Charles C. Thomas Publishers, Springfield, IL, p 298-418

Szpiro AA, Sampson PD, Sheppard L, Lumley T, Adar SD, Kaufman JD (2009) Predicting intra-urban variation in air pollution concentrations with complex spatio-temporal dependencies. Environmetrics 21:606-631

USEPA (United States Environmental Protection Agency) (1999) Ecological condition of estuaries in the Gulf of Mexico. EPA 620-R-98-004. USEPA, Office of Research and Development, National Health and Environmental Effects Research Laboratory, Gulf Ecology Division, Gulf

Editorial responsibility: Michael Moore (Guest Editor), Woods Hole, Massachusetts, USA
Breeze, FL

Vollmer NL, Rosel PE (2013) A review of common bottlenose dolphins (Tursiops truncatus truncatus) in the northern Gulf of Mexico: population biology, potential threats, and management. Southeast Nat 12:1-43

Waring GT, Josephson E, Maze-Foley K, Rosel PE (2015) U.S. Atlantic and Gulf of Mexico Marine Mammal Stock Assessments - 2014. NOAA Tech Memo NMFS-NE-231

Wells RS (2014) Social structure and life history of common bottlenose dolphins near Sarasota Bay, Florida: insights from four decades and five generations. In: Yamagiwa J, Karczmarski L (eds) Primates and cetaceans: field research and conservation of complex mammalian societies. Primatology Monographs. Springer, Tokyo, p 149-172

Wells RS, Schwacke LH, Rowles TK, Balmer BC and others (2017) Ranging patterns of common bottlenose dolphins Tursiops truncatus in Barataria Bay, Louisiana, following the Deepwater Horizon oil spill. Endang Species Res 33: $159-180$

Wilson B, Arnold H, Bearzi G, Fortuna CM and others (1999) Epidermal diseases in bottlenose dolphins: impacts of natural and anthropogenic factors. Proc R Soc B 266: 1077-1083

Wirsing AJ, Heithaus MR, Frid A, Dill LM (2008) Seascapes of fear: evaluating sublethal predator effects experienced and generated by marine mammals. Mar Mamm Sci 24: 1-15

Yeates LC, Houser DS (2008) Thermal tolerance in bottlenose dolphins (Tursiops truncatus). J Exp Biol 211: 3249-3257

* Zhu K, Zhou X, Xu S, Sun D, Ren W, Zhou K, Yang G (2014) The loss of taste genes in cetaceans. BMC Evol Biol 14:218

Submitted: June 16, 2016; Accepted: December 16, 2016 Proofs received from author(s): January 24, 2017 